\title{
ŞAH ABBAS DEVRINDE (1587-1629) IRAN'DA TICARî HAYAT
}

\section{Commercial Life of Iran in the Shah Abbas Period (1587-1629) \\ Dr. Cihat AYDOĞMuşoĞLu*}

\begin{abstract}
ÖZ
16. yüzyılın başında Safevi Devleti'nin kurulmasıyla birlikte Avrupalı devletlerin İran'a olan ilgisi artmıştır. Bu ilgi şüphesiz Osmanlı Devleti karşısında doğuda güçlü bir müttefik arayışı ile doğru orantılı idi. Avrupalı devletlerin İran'da kurulan Safevilere karşı gösterdikleri siyasi odaklı ilgileri daha sonra ticarî boyutta da gelişecektir. Safevi silsilesinin en kudretli hükümdarı Şah Abbas'in saltanat yılları siyasi ve ticarî ilişkilerin doruk noktasına çıktığı bir dönem olmuştur. Şah Abbas dönemi İran'ı doğudan ve batıdan diplomatik ve ticarî temsilcilerin buluşma noktası olmuştur. Biz bu makalede, merkezî otoriteyi sağlayıp güçlü bir devlet mekanizması geliştiren Şah Abbas devrinde Safevi Devleti'nin iç ve dış ticaretini anlatmaya çalışacağız.
\end{abstract}

Anahtar Sözcükler: İran, Safevi, Şah Abbas, Ticaret, ipek.

\section{ABSTRACT}

European states have increased interest in Iran at the beginning of the 16 . century with the establishment of the Safavid Empire. This interest is, undoubtedly, a strong ally against the Ottoman Empire was in direct proportion with the quest of finding. After a period of time, the interest of European states against the Safavids moved to the commercial dimension. Series for the years of the reign of the most powerful ruler of Safavid Dynasty Shah Abbas, political and commercial relations have been a time of climax. The period of Shah Abbas, Iran has been the meeting point of east and west, diplomatic and commercial representatives. In this article, we will try to explain internal and external trade of Safavid Empire during the reign of Shah Abbas who developed a strong state apparatus and provided central authority in Iran.

Key Words: Iran, Safavid, Shah Abbas, Trade, Silk.

\section{Giriş}

Adını Erdebilde'ki Safeviyye tarikatının kurucusu Şeyh Safiyüddin'den alan Safevi Devleti, 16. yüzyılın başında Rumlu, Şamlu, Tekelü, Ustacalu, Dulkadirli, Afşar, Kaçar, Bayburtlu ve Varsak gibi ekseriyeti Anadolu'dan İran'a giden Türk oymaklarının desteği ile Şah ismail tarafından kurulmuştur (Çay 1987: 565). Kuruluşundan itibaren güçlü bir Osmanlı Devleti'ni karşısında bulan Safeviler, Avrupalı hükümdarlarla ittifak arayışında olmuşlardır. Zira bu süreçte Avrupa hükümdarları da Batı'da genişleyen Osmanlılar karşısında Doğu'da güçlü bir müttefik arayışındaydı. Bu sebeple Safevilerin ilk yıllarından itibaren Batılı seyyah ve elçiler İran'a gelip gitmekteydi. Fakat bu süreçte ticari yönden açılım yapan

* Ankara Üniversitesi, Dil ve Tarih-Coğrafya Fakültesi, Tarih Bölümü Çğretim Üyesi, (aydogmusoglu@ankara.edu.tr) 
hükümdar Şah Abbas olmuştur. Çünkü o, Safevi Devleti'ni içte ve dışta güçlendirerek siyasi faaliyetlerinin yanına ticari faaliyetleri de ekleyebilmiştir. Zira Şah'ın ekonomi politikası, Osmanlı karşısında Batı'da müttefik bulma politikası ile paralel idi. Biz bu makalemizde, Şah Abbas' in ticari faaliyetlerini ve ekonomi politikasını anlatmaya çalışacağız. Şah Abbas devrinde Safevi ülkesinde ticaret hangi unsurların elindeydi, ne gibi ticari faaliyetler icra ediliyordu ve bu faaliyetlerin siyasi ittifaklara etkisinin nasıl olduğu gibi sorulara da yanıt aramaya çalışacă̆ız.

Safevi silsilesinin beşinci hükümdarı olan Şah Abbas, 1587 yılında tahta geçmiş, hemen ardından devletini yeterince güçlü bulmadığından Osmanlılarla bazı ödünler vererek sulh yapmıştır. Daha sonra ülkesindeki iç isyanları bastırarak merkezi idareyi sağlamış ve doğuda Horasan bölgesine devamlı saldırılarda bulunan Özbekleri bertaraf etmiştir. Düzenli ve modern bir ordu tesis eden Şah Abbas, idare merkezini Kazvin'den İsfahan'a nakletmiş ve burayı muhteşem yapılarla süslemiştir.

Safevi hükümdarları içersinde Avrupa ile ilişkileri genişletmek için en çok gayreti sarf eden hükümdar olan Şah Abbas, 1587-1629 yıllarını kapsayan saltanatının tamamında ülkesinin Avrupa ile ticaretini geliştirip, devletin refah seviyesini, gelir düzeyini ve dünya siyasetinde etkinliğini artırmaya çalışmıştır. Bu amaç doğrultusunda önce iç güvenliği sağlayıp, yeni yollar yaptırarak iç ticareti canlandıran Şah Abbas, Hıristiyan tüccarlara sağladığı kolaylıklarla da İran'ın dış ticaretini geliştirmeye gayret etmiştir. O, 1600 yılında yayınladığı bir fermanla İran ile ticaret yapmak isteyen Hıristiyan tüccarlara birçok kolaylıklar ve ayrıcalıklar sağlamıştı (Ramazani 1966: 28). Yayınladığı bu fermanda yerel hâkimlerin Hıristiyan tüccarlarla çatışmasını önlemiş, gümrük vergisi hususundaki zorlamaları kaldırmış ve dini liderlerin Hıristiyanlara baskı yapma ihtimalini ortadan kaldırmışı (Sykes 1915: 261). Yine Şah Abbas, Anthony Sherley için yayınladığı bir fermanda tüm Hıristiyan tüccarların her zaman için gümrük vergilerinden muaf olduğunu, dini özgürlüklerinin ve Şah'a ait tüm bölgelere özgürce gidebilmelerinin kabul olunduğu belirtmişti (Savory 1987: 80).

\section{Şah Abbas Devrinde Safevi Devleti'nin Dış Ticareti}

Şah Abbas devrinde dış ticaret en çok Osmanlı Devleti ve Hindistan ile yapılıyor, İran'ın başlıca ihraç malı olan ipek, kervanlarla özellikle Bursa, Tokat ve Halep'e gönderiliyordu. Osmanlı ülkesine gelen ipeğin büyük bir kısmı oradan Avrupa'ya sevk ediliyor, Osmanlılar da bundan önemli bir gelir sağlıyorlardı. Şah Abbas bu kazancı kesmek için Osmanlı toprakları üzerinden ipek sevkiyatını durdurmak istediyse de başarılı olamadı. Bunun önemli sebeplerden biri, Şah Abbas'ın ithal ettiği maddelerin başında yer alan işlenmiş bakırı Osmanlı 
Devleti'nden almasıdır (Sümer 1988: 19). Ayrıca İran, Osmanlı Devleti'nden gümüş ve altın ithal ediyordu.

Culfa Ermenileri, Osmanlı Devleti'nden Tebriz'e gelen kervan ticaretinde aktif rol oynuyorlar, İran'a gümüş ve altın getiriyorlardı. Böylece İran'a gelen gümüş ve altınlar, Tiflis, Erivan ve Tebriz'de bulunan darphanelerde eritilip paraya dönüştürülüyordu. Yine Avrupa'dan ve Osmanlı İmparatorluğu'ndan Halep üzerinden kervanlarla Basra'ya oradan İran'a ve Fars Körfezi'ne- para akışı [madeni para] sağlanıyordu. Bir de Hac kervanları dönüşlerinde kıymetli madenler getiriyorlardı fakat bu durum Şah Abbas'ın özellikle Meşhed'deki İmam Rıza Türbesi'ne daha fazla önem vermesiyle biraz sekteye uğramıştır. Ayrıca Anadolu'daki Celali kargaşası kervan ticaretini, dolayısıyla kıymetli maden ve külçe akışını sekteye uğratmıştı. Durum böyle olunca Osmanlı Devleti'nin uyguladığı kısıtlamalar ve ticarete sekte vuran aradaki savaş dönemleri bu para [madenlerin] akışını etkiliyor ve İran'da enflasyona sebep oluyordu. Safevi Devleti, kendi üretmediği ve bu sebeple Osmanlı Devleti'nden ithal ettiği bakır, gümüş ve altın için kaynağı, ipek ticareti ile Hindistan'dan gelen transit ticaretten (çivit ve dokuma) sağlıyordu (Floor ve Clawson 2000: 357). Tabii şunu da belirtmekte fayda vardır ki İran'da altın çok az -genellikle Nevruz bayramlarında ve cülûs törenlerinde pîşkeş-hediye olarak- kullanılıyordu ama gümüş çok iyi işleniyor ve her tarafta rayiç para birimi [abbasî'-mahmudî] olarak kullanılıyordu (Felsefî 1375: 1187).

\section{Ipek Ticareti}

İran ipeği, Osmanlı toprakları üzerinden Avrupa'ya taşınıyordu. Ucuz ve kaliteli İran ipeği, Halep ve İzmir'de bolca bulunmaktaydı. Örneğin İran, 1621 yılında 6000 balya ham ipeği Halep üzerinden Avrupa'ya ihraç etmişti (Matthee 1999: 91). Bu iş Venedik ve İngiliz tüccarları tarafından yapılıyordu. Tabii iki devlet arasında ipeğin Avrupa'ya taşınmasında -transit ticarette- rekabet yaşanıyordu. İran kervanlarının gecikmesi sonucu zaman zaman patlak veren krizlere rağmen ipek, Osmanlı-İngiliz ticaretinin esasını oluşturmaktaydı. İngiliz tüccarlar, Halep üzerinden Basra'ya, buradan Fars körfezi yoluyla Hürmüz'e ve Hindistan'a ulaşıyorlardı. İngilizlerin İran'dan ipek ithalatına duyduğu ilgi Şah Abbas döneminde 1621 tarihinde Levant'tan ithal edilmek üzere 117.740 libreyi (53.395 kg) bulmuştu. Tabii bu rakam Osmanlı toprağından ithal edilen İran ipeğinin oranıdır. İngilizler bu iş için Osmanlı Devleti'ne vergi ödüyorlardı. Bu sebeple ipeği daha ucuza alabilmek amacıyla Trabzon üzerinden İran ile doğrudan bağlantı kurmaya kalkışmışlardı. Fakat bu teşebbüs İran ipeğinin Suriye'deki en büyük müşterisi olan Venedik ile birlikte Ermeni ve Gürcü ipek

' Abbasî, ilk defa Şah Abbas döneminde basımına başlanan ve onun tüm saltanatı boyunca geçerli olan bakır paralara verilen isimdir. 
tüccarlarını da telaşa düşürmüştü. Ayrıca girişimi haber alan Osmanlı Devleti, İngilizlerin bu projesini yasaklamıştır (Inalcık 2000: 434-435).

Şah Abbas zamanında Osmanlı Devleti ile Safevi Devleti arasında sık sık ambargolar uygulanıyor ve her türlü malın geçişi yasaklanıyordu. Tabii bu ambargoların ekonomik sonuçları Osmanlılar, Safeviler ve İtalyanlar için bir hayli olumsuz oluyordu. Fakat bu gibi tedbirler, yasaklamalar ve ambargolar sürekli ve kalıcı olmuyordu. Çünkü iki devlet için de ticaretten gelen gelir önemliydi. İran, ipeğini satıp para kazanırken Türkiye, bu ticaret sınırları dâhilindeki vilayetlerden yapıldığından vergisini alıyordu. Ayrıca Osmanlı Devleti, Amasya, Bursa, İstanbul, Mardin ve Diyarbakır'daki ipekli dokuma sanayileri ile İran'dan gelen ham ipeği işliyordu. Böylece ipek ticareti iki devletin ekonomisinin gelişmesinin yapı taşını oluşturuyordu. Avrupa'da ipekli kumaş kullanımının ve ipekli dokuma sanayilerinin yaygınlaşması Safevi ve Osmanlı devletlerinin ekonomisinin yararına olmuştu. Böylece her iki imparatorluk, kamu gelirleri ile gümüş stoklarının önemli bir bölümünü Avrupa ile olan ipek ticaretinden sağlar hale gelmişti (İnalcık 2000: 270).

Yeni ve sürekli büyüyen ipek piyasaları, ihtiyaç duydukları ham ipeği Osmanlı İmparatorluğu vasıtasıyla i̇ran'dan sağlıyordu. Böylece Batı́nın genişleyen ipek piyasası, İran ve Osmanlı ekonomileri için yeni bir refah kaynağı haline gelmişti. Öyle ki 1620'lerde Avrupa'nın toplam İran ipeği ithalatı yılda bir milyon lidreyi (384.800 kg) buluyordu (Inalcık 2000: 300). 1626-1631 yılları arasındaki periyotta ise İran'ın ham ipeği, Avrupa'nın Asya'dan yaptı̆̆ı ithalatta ikinci sırada yer alıyordu (Floor ve Clawson 2000: 346). Böylece Safevi Devleti'nin bütçesinin en önemli kısmını, ipek ticaretinden elde edilen gelirler oluşturmaktaydı. İran ham ipeğinin Osmanlı toprakları içinde satıldığı en büyük iki merkez Halep ve Bursa idi. İstanbul ve Kahire'den sonra Osmanlı İmparatorluğu'nun üçüncü büyük şehri olan Halep'in zenginliğinin sebebi İran'dan gelen ipek kervanlarıdı (Floor ve Clawson 2000: 346). 1578-1590 Osmanlı-Safevi savaşı sırasında ipek ticaretinde bir düşüş olmasına karşılık, İstanbul Barışı'nın getirdiği sulh döneminde (1590-1602), Halep pazarı eski canlılığına kavuşmuş ve 1603 yılında tekrar iki devlet arasında savaş patlak vermesinden hemen önce en yüksek seviyesine çıkmıştı. 1612 yılında imzalanan Nasuh Paşa antlaşmasının görüşmelerinde Osmanlı heyeti, İran'ın senelik 32 ton ipek göndermesinde ısrarcı olmuştu. Çünkü Osmanlı Devleti için ipek ticaretinden elde edilen gelir hayati derecede önemliydi. Hatta Osmanlılar, Avrupalıların İran ile direkt temasa geçip, İran ipeğini kendi toprakları haricinde bir güzergâhtan götürmeleri ihtimalinden çok kaygılanıyorlardı. 17. yüzyılda, bu iki önemli merkeze rakip olarak İzmir ortaya çıkacak ve İran ham ipeğinin Avrupalılar açısından en önemli pazarı haline gelecektir. İzmir'in önem kazanmasıyla birlikte Şah Abbas'ın İran ipeğini doğrudan Avrupa'ya satma 
politikası çerçevesinde işlev kazanan İran Ermenileri, önce İzmir'de aktif hale gelecekler ve daha sonra 17. yüzyılda Livorno'nun Avrupa'da önemli bir ipek pazarı olmasında önemli roller oynayacaklardır.

Şimdi “Iran'in ipek ticareti kimlerin elindeydi?" sorusuna cevap arayabiliriz. Burada ilginç bir tespit olarak şunu belirtmekte fayda vardır ki Halil İnalcık, 15. ve 16. yüzyıllarda İran'dan Bursa'ya gelen ipek tüccarının ezici çoğunluğunu Farsî ve Azerî Müslümanların oluşturduğunu belirtirken, Ahmed Tâcbahş, Şah Abbas döneminde ipek alım-satımında Ermenilerin önemli rol oynadıklarına değinmektedir. Bu da 16. yüzyılın ikinci yarısından itibaren bir değişim yaşandığını ve özellikle Şah 1 . Abbas zamanında ipek ticaretinde Ermenilerin öne geçtiğini akla getirmektedir. Bundaki sebep Şah Abbas devrinden başlayarak Ermenilere öncelik verildiği ve bunların Müslüman tüccarının yerini aldığıdır. Özellikle ipek ticareti, Şah Abbas ile birlikte Ermenilerin eline geçmiştir. Çünkü Şah Abbas, Ermenileri "Şah'ın temsilcisi" sıfatıyla ipek ticaretinde kullanmıştır. Öyle ki Şah Abbas'a ait saltanat ambarlarında toplanan ipek, Ermenilere dağıtılıyor, onlar da ipeği Hindistan'a veya Osmanlı toprakları üzerinden Avrupa'ya gönderiyorlardı. Bu sayede toplanan para Şah Abbas'in hazinesinde birikiyordu (Felsefí 1375: 1120). Zaten Şah Abbas'in önemli bir Ermeni nüfusu başkent İsfahan'a naklettirdiği ve bunlara ticaret hususunda iş yapabilmeleri için birtakım mali yardımlarda bulunduğu bilinmektedir. Hatta Ermenilerin, başkent ìsfahan'da Nakş-Cihan Meydanı́nın batısında kendilerine özel dükkânları vardı ve bu dükkânlarda İngiliz ve Hollanda mahutu [çuha], kırmızı Venedik dokumaları ve sâir Frenk kumaşları satıyorlardı. Bunlar ipek karşıı̆ı̆ı Avrupa'dan İran'a gelen mallardı. Şah, özellikle dış ticarette Ermenilerin Avrupa ile olan ilişkilerinden faydalanmak istemişti. Böylece Ermeniler, Venedik ve Livorno'ya kadar İran'ın tüm dış ticaretine hâkim olmuşlardı. Hatta İran Ermenilerinin, Venedik ve Livorno dışında Amsterdam ve Paris'de özel temsilcileri vardı.

İranlı tüccarlar, ellerindeki ham ipeği sattıktan sonra elde ettiği nakitle Bursa'da mal alımına (kalay, yünlü kumaş, baharat v.s.) girişiyorlardı. Böylece Bursa, hem İran ipeğinin başlıca uluslararası pazarı hem de İran'a yapılan her türlü ihracatın antreposu haline gelmişti. Öyle ki Şah Abbas'ın tahta geçmesinden 1 yıl önce 1586 yılında Osmanlı İmparatorluğu ile Safevi Devleti savaş halindeyken beklenen İranlı tüccarın ancak yarısının gelmesi, Bursa piyasasında ham ipek fiyatlarının firlamasına, Bursa'daki ipekli dokuma tezgâhlarının dörtte üçünün durmasına ve çoğu büyük dokumacının iflasına yol açmıştı. Yine 1603-1612, 1615-1618 ve 1624-1639 yıllarını kapsayan Osmanlı-Safevi savaşları arz darlığı yaratıyor ve keskin fiyat dalgalanmalarına yol açıyordu. Fiyatların yükselmesinde Batı'dan gelen talebin artmasının da etkisi vardı. İran tüccarı, Bursa'da kalay ve batı yünlülerinin yanı sıra Körfez'den gelme incileri, 
Mısır ve Kıbrıs'tan gelme șekeri, hatta Hindistan'dan gelme baharatı da satın alıyordu. 1600 dolaylarında, İran'ın Osmanlı Devleti'nden ithal edilen kalay ve yünlü kumaş ihtiyacı tahminen 2.000 balya kumaş ve 40-50 ton kadar kalaydı (Inalcık 2000:276,282,283).

İpekli dokuma sanayinin İngiltere'ye girişi 1. Elizabeth (1558-1603) dönemine rastlamaktadır. Bu dönemde hızla gelişen ipekli dokuma sanayisi için ham ipek ithali, 1620 tarihlerine gelindiğinde ülkenin en büyük ithal kalemi olmuştu. 1617'de İngiliz ipekli dokuma sanayinin yılda tahminen 300-600 balya (27-54 ton) ham ipeğe ihtiyaç göstermesine karşıllk Şah Abbas'ın önerdiği sevkiyat miktarı 2000-3000 balyayı buluyordu (Inalcık 2000: 299). Bu sebepten İniltere, doğudan aldığı ham ipek için ödediği kıymetli madenin ülkesinden çıkmaması için daha ucuz ve alternatif seçenekler peşinde idi. Şah Abbas, bir ara hem ipeği daha ucuza almak isteyen İngiltere'nin isteği hem de Osmanlı Devleti'nin ipeğin geçişinden aldığı vergi gelirini kesmek amacıyla İran ipeğinin rotasını değiştirmek için uğraştıysa da muvaffak olamamıştı. Zira bu işe önce İran'da üretilen ipeğin büyük bir kısmının satımını gerçekleştiren Ermeniler karşı çıkıyorlardı. Çünkü Ermeniler, Türkiye-İran arasındaki ipek ticaretinde aracılık yapıyorlar ve bu konumlarını kaybetmek istemiyorlardı. Bu sebeple Şah Abbas, ipek ticaretinin rotasını değiştirip, ipek tekelini de İngilizlere vermek isteyince Ermeniler hemen temsilcilerini Şah'a göndermişler ve ne yapıp edip bu işi engellemişlerdi. Osmanlı Devleti de bu gelişmeleri yakından takip ederek, zamanında önlem alıp Sherley kardeşlerin fikirleri doğrultusunda entrikalar çevirmeye kararlı olan Şah Abbas'ı engellemiştir.

Şah Abbas, 1603-1629 yılları arasında ipek yolunu Osmanlı topraklarından Hint okyanusuna kaydırma planını denemiştir. Bu bir anlamda kervan ticaretinden deniz ticaretine geçmek demekti. Şah'ın düşüncesine göre Hint okyanusunda üstünlük kurmuş olan İngiliz ve Hollandalılar, Osmanlı limanlarında ödedikleri ekstra vergilerden kurtulmak için bu plana heves edebilirlerdi. Böylece Osmanlı-Safevi rekabeti ekonomik boyuta da taşınmış oluyordu. İranlılar ipek ihracatını yasaklarken, Osmanlılar da İran'a altın ve gümüş sevkiyatını durdurmaya yönelik önlemler almışlardı. Bu önlemler İran'da parasal bunalımı daha da keskinleştirdi. Şah Abbas, bu sorunu Bender Abbas'da kuzeylilere büyük miktarda ipek satarak çözmeye çalıştı. iki devlet arasında uygulanan bu ambargonun olumsuz etkileri Osmanlı ekonomisinde de hissedilir olmuştu. İpek ve baharat yolunun Bağdat yüzünden iki devlet arasında savaş çıkıp 1623 yılında kesilmesiyle Osmanlı hazinesi önemli miktarda gümrük gelirinden mahrum olmuştu. Durum Osmanlı Imparatorluğu'nun dünya ticaretinden yalıtılması haline dönüşüyordu ki dönemin siyasi konjonktürü bu tehlikeyi kendiliğinden ortadan kaldırmış ve Şah Abbas'ın yaptığı bu plan hiçbir zaman tam anlamıyla gerçekleşmemiştir. Zira ipek rotasını değiştirmek öyle 
kolay bir iş değildi. İspanya, Venedik ve İngiltere gibi devrin önemli devletlerini razı etmek gerekiyordu. En başta İran ipeğini Osmanlı üzerinden Avrupa'ya taşıyan Venedik bu işe karşıydı. Çünkü Osmanlı topraklarında Suriye'de bulunan pazarlar, Venedik ekonomisi için hayati öneme haizdi. İspanya Kralı hem bu öneriyi uygulanabilir bulmamış hem de Venedik piyasası ve pazarları bu işten zarar göreceğinden Şah'ın planına yanaşmamıştı. Ayrıca Osmanlı Devleti ile herhangi bir sorunu olmayan İspanya Kralı́nın Safeviler için önemli olan Fars körfezindeki önemli stratejik limanlarda da gözü vardı. Venedik gibi İran ipeğini Osmanlı üzerinden Batıya taşıyan İngiltere'ye gelince; Osmanlı karşısında İran Şah'ının fiili yardım talebine yanaşmayan İngiltere Kralının ticarî konular hakkında görüş sorduğu Doğu Hindistan Kumpanyası da bu işe kesin olarak karşıydı. Çünkü Osmanlı ile ticaretin kesilmesi kendilerinin en önemli gelirlerinin kesilmesi demekti. Ayrıca Şah'ın çizdiği rota uzun ve kâr kesin değildi. Bunlara ilave olarak İran, Osmanlı topraklarından süzülüp gelen kıymetli madenlere bağımlılı̆̆ıdı. İngiltere, bir ara ipek ticaretinin Moskova üzerinden yapılmasına taraftar görünüp İran'ın kıymetli maddelere olan bağımlı̆ını karşılamayı taahhüt ederek Şah'tan ipek karşılığındaki nakit ödemelerde(altın olarak) bazı kolaylıklar talep etse de bu taahhüdün zamanında ve istenilen oranda karşılanacağ değildi. Şah, İngilizlere nakit ödemelerde kolaylık sağladıysa da Moskova üzerinden olan ipek ticareti hiçbir zaman istenilen düzeye gelmemişti. Şah, ipek ticaretinin kuzeyden olması için müzakerelerde bulunmak amacıyla 1610 yılında Katolik keşiş Pere Juan Tade'yi Lehistan ve Rusya'ya gönderdi (Felsefî 1375: 1909). Fakat bu girişimden hiçbir olumlu netice elde edemedi. Ayrıca 1618 yılında Osmanlı Devleti ile Safevi Devleti arasında Serav Barışı yapılınca bol miktarda ipek ile diğer emtia Bağdat üzerinden tekrar Halep piyasasına akmaya başlamıştı. Serav Barış Antlaşması ile İran, vergi olarak yılda 200 balya ipek vermeyi kabul etmiş ve antlaşmanın yürürlüğe girmesinden sonra Osmanlı Devleti ile İran arasında ambargolar kalkmıştır. Bunun sonucunda Bağdat'tan gelen bir kervanın bin balya İran ham ipeği getirmiş olduğu müjdesi en çok Venedik tüccarını sevindirmişti. Ambargoların kalkmasına ve ticaret yollarının açılmasına rağmen yine de bir miktar Acem ipeği, kuzey İran ve Bender Abbas üzerinden Rusya ve İngiltere'ye ulaşmaya devam etmiştir. Örneğin 1623 yılında 75 tane Rus tüccarı İran'a gelmiş ve 4440 libre ipek gemilerle Astarhan üzerinden Rusya'nın çeşitli şehirlerine taşınmıştır (Matthee 1999: 92).

Görüldüğü üzere İran ticareti, Osmanlı Devleti toprakları üzerinden hiçbir zaman bütünüyle yok olmamış ve devrin şartları kendiliğinden Şah Abbas'ı bertaraf etmişti. Hatta İran'dan Halep'e ve diğer Osmanlı şehirlerine uzanan kervan ticareti tüm Safevi tarihi boyunca devam etmiştir. Sonuç olarak, iki devlet de önemli bir gelir kaynağı olan ticaret hususunda (ipek, baharat, kalay, bakır v.s.) birbirine muhtaçtı. İpek, İran için en önemli gelir kaynağı olurken Osmanlı ipek endüstrisi de İran ipeğine muhtaçtı. Hatta Doğu-Batı 
ticaretinden önemli gelir elde eden Avrupa'nın tüccar devletleri de Osmanlı Devleti ile Safevi Devleti arasında faal bir ticaret yolunun olmasından yanaydı.

\section{Doğu Hindistan Şirketi'nin İran'daki Faaliyetleri}

Şah Abbas döneminde İran'ın ekonomik ve ticarî hayatı anlatılırken elbette İngilizlere ait Doğu Hindistan Şirketi'nin temsilcilerinin Şah ile olan görüşmelerine değinmek gerekmektedir. Çünkü bu şirket zamanla Fars Körfezinde Portekiz' in yerini alacak, böylece İranlılar çoğunluğunu pamuklu ile çivit boyasından oluşan Hint mallarını bu şirket aracılığıyla almaya başlayacaklardır. 1600 tarihinde kurulan Doğu Hindistan Kumpanyası, her ne kadar özel bir şirket gibi görünse de İngiltere Kraliçesi adına iş yaptığı için Ingiltere Devleti'ni temsil ediyordu.

İngilizler tarafından kurulan Doğu Hindistan Şirketi, kurulduktan sonra Babür Devleti hükümdarından izin alıp Hindistan'da ticaret yapmaya başlamışlardı. Fakat Hindistan gibi ılıman iklime sahip bir ülkede getirdikleri İngiliz kumaşları ve çuhalarını satamayan şirket yetkilileri çareyi başka pazarlar aramakta bulmuşlardı. Tam bu sırada şirket için çalışan seyyah Richard Steel'in İran ile ilgili raporu geldi. Bu raporda; İran'ın iklimin birkaç ay soğuk geçtiğini ve orada yün kumaş kullanmak zorunluluğu olduğu, Osmanlı-Safevi savaşının Avrupa kumaşlarının İran'da az bulunmasına neden olduğunu ve böylece İngiliz ticarî mallarının satılması için uygun bir ortamın oluştuğu ve ipeğin fiyatının da Halep'ten daha ucuz olduğu vurgulanıyordu. Gerçekten de Fars körfezi üzerinden satılan İran ipeği, Akdeniz yoluyla satılan Osmanlı ipeğinden daha ucuza mal oluyordu. Bunun üzerine stoklarını eritmek isteyen şirketin müdürü, çuha ve kalın kumaşların İran için gerekli olacağını düşündü. Ayrıca ipeğin diğer yerlere göre yarı yarıya ucuz olması da son derece önemli bir kazanç sağlayabilirdi. Fakat bunların gerçekleşmesi için İngiltere'nin İran'da bir pazar oluşturması gerekliydi. Böylece İngilizlere ait Doğu Hindistan Kumpanyası́nın ilgisi İran'a yönelmiştir.

Hindistan'daki faaliyetlerini ilerlettikten sonra diğer pazarlara açılmak isteyen İngiliz Doğu Hindistan Şirketi'ne ait ilk gemi[James], 1615 Aralık ayında Portekiz engellemelerine rağmen Fars Körfezi'ne girerek Şah Abbas'a ticarî projeleri için bir teklifte bulunmuştur. Böylece Doğu Hint Şirketi'nin ilk temsilcisi Şah'ın sarayına ulaşmış oluyordu (Tâcbahş 1340: 198). Başkent İsfahan'da Doğu Hindistan Kumpanyası Başkanı John Crauther tarafindan karşılanan ve Şah ile görüşen Steel'in amacı, Şah Abbas'tan ticarî bir imtiyaz koparmak ve bir ticaret antlaşması yapmak idi. Aslında kumpanyanın başkanın İran'da bulunmasının amacı ülkenin ticarî potansiyelini öğrenmek ve mümkün olursa bir antlaşma yapmak idi. Böylece ticaretin başlaması için hevesli olan Şah Abbas, Steel'i çok iyi karşılayıp bir ferman yayınladı ve Fars körfezi hâkimlerinin 
İngilizlere saygılı davranmalarını, onların gemilerinin engellenmemesini ve mallarını nereye götürmek isterlerse oraya yönlendirilmelerini istedi. Ayrıca Şah Abbas, Hürmüz adasının $90 \mathrm{mil}[144 \mathrm{~km}]$ doğusunda anakarada bulunan Cask Limanı'nda İngilizlere bir ticaret istasyonu kurmaları iznini vermiştir (Farmayan 1969: 22). Tam bu sıralarda Robert Sherley de Avrupa'dan dönmüş ve Steel ile Şah arasında aracı rolü oynamıştı. Bu ilk temsilcinin gelmesi ile birlikte şirketin İran'a olan ilgisi artmış ve kumpanya, temsilcilerine emirler gönderip İran ile ilgili detaylı bilgiler istemiştir. Ayrıca Hindistan'da bulunan İngiliz elçisi de Doğu Hindistan Şirketi'ne yardımcı oluyor ve bazı tavsiyelerde bulunuyordu. Şirket, öncelikle İran'da ticarete kimin ve hangi ürünün hâkim olduğu ile ticaret için İran'ın hangi bölgesine yerleşmenin daha uygun olacağı hususlarını öğrenmeye çalışmıştır. Şirkete gelen raporlar doğrultusunda Ermenilerin İran ticaretinde faal oldukları ve İran ipeğinin en önemli ticarî meta olduğu anlaşılmıştı. Ayrıca şirket, İran'ın ipek ürünlerinin tamamen İran Şah'ına ait olduğunu da öğrendi. Tabii bu arada kurnaz bir hükümdar olan Şah Abbas, Osmanlılar aleyhine i̇spanya ile de ticaret antlaşması yapmak için temas kuruyordu. Şah'ın bu şekilde iki rakip devlet ile temasta olması Hindistan'daki İngiliz elçisi Thomas Roc [Roe] tarafından öğrenilmişti. Bunun üzerine İngiliz elçisi gelişmelerden hem kumpanyayı haberdar etmiş hem de Şah'a bir mektup yazıp, İspanya ile ticaret antlaşması yaparak onlara ticaret izni vermesinin Doğu Hindistan Kumpanyası ile yapılan önceki antlaşmalara aykırı olduğunu söylemiştir. Fakat elçinin bu itirazı Şah tarafından kabul görmemiş ve Şah, İspanyollarla olan görüşmelerini kesmemiştir. Bunun üzerine İngilizler ticarî imtiyaz koparmak ve Fars körfezi üzerinden yapılan ticaretin tamamına hâkim olmak için Şah nezdinde yaptıkları faaliyetlerine yoğunluk kazandırmışlar ve birkaç tüccarını İran'a Şah Abbas ile görüşmeye göndermişlerdir. Şirket temsilcileri içleri yaklaşık 6,500 sterlin değerindeki İngiliz ticarî malları dolu gemilerle Kasım $16 ı 6$ yılında Cask limanına ulaşmışlardır (Tâcbahş 1340: 201). Bu heyetten Edward Connok, Şah ile görüşmek amacıyla başkent ìsfahan'a gitmiş (31 Mart 1617), fakat Şah Abbas o sırada Kafkaslarda olduğundan Connok da oraya gönderilmiştir. Kafkaslarda gerçekleşen görüşmede Şah Abbas, İngiltere Kralı'nın kendi [büyük] kardeşi olduğunu söyleyip onun sağlığına bir kadeh şarap içti (Pâzuki 1317: 347). Temsilci Edward Connok, Şah'tan İngiliz gemilerinin İran ipeğinin Avrupa'ya satışı amacıyla Fars Körfezi'nde gidip-gelmeleri için özel bir izin verilmesini talep etti. Bunun üzerine Şah Abbas, İngilizlere izin verip güneyde istedikleri limanı seçebileceklerini söyledi. ilave olarak Şah Abbas, yıllık 1000-3000 balya ipeği muayyen bir bedel karşılığında İngilizler (kumpanya) için temin edebileceğini ve bu ipeğin gümrük vergilerinden muaf olarak Cask limanından götürülebileceğini söyledi (Savory 1374: 110). İngiliz temsilciler, ipek fiyatının dörtte birini nakit, geri kalanını ise İngiliz ticarî malı (çuha, yünlü ve pamuklu giysiler, baharat, kalay, kurşun) vererek karşılanması teklifinde bulundular (Ferrier 1973: 41,44). 
Daima İran ipeğinin daha iyi satılmasına taraftar olan Şah Abbas bunu da kabul etti. Ayrıca Şah, İngilizlere izin verip İran sarayında daimi bir temsilci bulundurmalarına ve serbest ticarete de müsaade etti. Bunun üzerine kumpanya temsilcisi Şiraz ve İsfahan'da ticaret merkezleri oluşturdu. Hint okyanusunda Portekiz ve İspanyollarla uğraşan ve bu sebeple ipek ticaretinin Moskova üzerinden yapılmasına çaba gösteren İngilizlere verilen bu tavizler, tabii ki Safevilerin o sırada Osmanlı Devleti ile savaşta olmasındandı. Fars körfezindeki ticaretin kilidi konumunda olan Hürmüz adasını bir gün almayı kafasına koyan Şah Abbas'ın, Portekiz karşısında İngiliz gemilerine ihtiyacı olması da bu tavizler için geçerli bir neden oluşturmaktaydı.

Doğu Hindistan Kumpanyası temsilcisi Edward Connok, 1617 yılında Hürmüz'de vefat edince (Portekizlilerin zehirlettiği de söylenmektedir), yardımcısı Thomas Barker onun yerini aldı. Şah Abbas, bu temsilciyi diğer sefirlerin yanında huzuruna kabul etti ve çok şefkat gösterdi. Yapılan müzakereler neticesinde fiyatının önceden peşin veya İngiliz malı olarak verilmesi karşılı̆ında yılda 600 yük (93,5 ton) ipek vermeyi kabul etti. Fakat Thomas Barker'ın ipeğin fiyatının sabit olması yönündeki talebini kabul etmedi (Tâcbahş 1340: 202).

H.1028 (M.1618/1619) tarihinde Gyles Holles, İran'a geldi ve Şah'a kumpanya adına getirdiği mektubu sundu. Bazı müzakerelerden sonra hem Şah Abbas'ın düşüncelerinde hem de kumpanyanın isteklerinde bazı değişiklikler oldu. Şah Abbas, Osmanlı toprağından gönderilmemesi şartıyla İran ipeğini tamamen İngilizlere satacağına dair söz verdi. Tabii buna ilk olarak Ermeniler itiraz etti. Çünkü bu proje uygulanırsa iki devlet arasında ipek ticaretinde aracılık yapan ve mallarını Türkiye üzerinden Avrupa'ya götüren Ermeniler bundan zarar görecekti. Ermenilerin şiddetli muhalefeti üzerine Şah Abbas, Doğu Hindistan Kumpanyası temsilcilerini ile Ermeni ve İspanyol tüccarlarını çağırtarak bir komisyon oluşturdu ve ipeğin fiyatının müzakere edilmesini istedi. Kim daha fazla fiyat verirse İran ipeğinin inhisarını ona vereceğini söyledi. Şah'ın İspanyol temsilcisini de çağırmasının sebebi, bir ara elçisi vasıtasıyla ipek tekelini Hürmüz-Lizbon arası yapılacak deniz ticareti ile İspanya Kralı́na teklif etmiş olmasındand. Fakat Şah'ın bu davetine ìspanya temsilcisi kendi devleti tarafından bu iş için bir emir almadığını söyleyerek katılmadı. Sonunda Ermeni tüccarları verdikleri yüksek fiyatla $-108 \mathrm{~kg}$ ipeği 50 Tuman'a almayı taahhüt ederek- müzayedeyi kazandılar (Tâcbahş 1340: 203). Görüldügü üzere, Şah Abbas'in ezeli rakibi Osmanlı Devleti'ni ipek ticareti üzerinden elde edilen gelirden mahrum etmek isteyen bu gibi âfaki projeleri zamanın konjonktüründe uygulamaya konulamıyordu. 
ileride İngiliz gemilerinin yardımı ile Hürmüz'e saldırıp Portekizlileri bu adadan atmayı kafasına koyan Şah Abbas, Hürmüz'e karşı bir kontrol noktası olmak üzere İngilizlerin Cask Limanı'na daha çok yerleşmelerine izin vermişti. Böylece 1619 yılında Cask Limanı'nda bir İngiliz fabrikası kurulmuş ve aynı yıl 5 gemilik bir İngiliz filosu Cask'a ulaşmıştı (Farmayan 1969: 23). 1620 yılında ise Doğu Hindistan Kumpanyası'nın yeni temsilcisi Edward Monox, İsfahan'a gelip Şah'ın huzuruna çıktı. Stratejik bir öneme sahip Hürmüz adasını Portekiz'in elinden almak için -kendi devletinin donanması olmadığından- İngilizlere ait Doğu Hindistan Kumpanyası şirketine ait gemilere ihtiyaç duyan ve bu konuyu Ingilizlerle müzakere etmek isteyen Şah Abbas, şirketin temsilcisini sıcak karşılamıştır (Mehdevi 1377: 90). İran ile ticaret yapmayı kesin olarak kafalarına koyan, Hint okyanusunda ìspanyol ve Portekizlilerin sahip olduğu konumu ele geçirmeye çalışan İngilizler, Şah'ın bu talebini olumlu karşılamışlar ve onunla Fars körfezinde işbirliğine yanaşmışlardı. Ayrıca Şah Abbas'ın Doğu Hindistan Kumpanyası'na, Bender Abbas ismini alacak limanın gelirinin bir kısmı ile İran ipeğinin Gilan'dan İsfahan'a taşınmasındaki masrafı bizzat ödemeyi taahhüt etmesi İngiltere'yi hoşnut etmişti. Şah'n bu lütfundan hoşnut olan İngilizler 1621 yılında 5 gemi ile mallarını Cask Limanı'na getirdiler. İran Şah'ı için de hediye olarak 6 atla çekilen altından bir at arabası getirmişlerdi. Tabii ertesi yıl (1622) Şah, İngilizlerin yardımıyla Portekizlileri Hürmüz'den çıkarmıştı (İskender Bey 1387: 979-982). Daha sonra ham ipek akışını yeni inşa ettirdiği Bender Abbas limanı yönüne çevirebilmek için İran'ın kendi içindeki ipek ticaretinde tekel uygulamak zorunda kaldı. İngiltere'ye vaat edilenlere gelince; şartları kendi çıarı için kullanmasını çok iyi bilen Şah Abbas, İngilizlerin Fars körfezini korumak için kendi savaş gemilerini devamlı olarak körfezde tutmamalarını bahane ederek Ingiltere'ye ve kumpanyaya vaat ettiği sözleri yerine getirmedi (Tâcbahş 1340: 204). Antlaşmaların uygulanmasını isteyen kumpanya sekreterinin sözlerine karşılık İran Sadrazamı, İngilizlerin her yıl İran'dan kanunsuz olarak çok miktarda altın ve para çıardıklarını söyledi. Böylece ne kumpanya ne de Ingiltere Şah'a yardım etmekle bir kazanç sağlamışlardı.

Şah Abbas, Hürmüz adasını Portekiz kontrolünden çıkardıktan sonra adanın karşısındaki Gemburun Limanı'nın yerine tesis edilen Bender Abbas'ı Fars Körfezi'nin ticaret merkezi yapmaya gayret etmekteydi. Bu amaçla Cask Limanínda buluna Ingilizleri buraya naklettirdiği gibi Cava ve Sumatra gibi okyanus adalarına gidip-gelen Hollanda'nın 1623 yılında Bender Abbas'da ticaret merkezi kurmasına ve bu limana yerleşmesine izin verdi. Hatta Şah Abbas, İngilizlere Bender Abbas'da konsolosluk açma ve İran'dan ipek satın alıp İngiliz dokumalarını satma iznini vermişti. Bir müddet sonra Hollandalı tüccarlar, Hubert Visnich vasıtasıly Şah'tan ipek ticaretine katılmak hususunda izin isteyince Avrupalı devletlerin aralarındaki rekabetten faydalanarak İran ipeğini daha pahalıya satıp daha fazla kâr etmek isteyen Şah Abbas, Hollandalılara ait 
Doğu Hint Şirketi ile 21 Kasım 1623 tarihinde bir antlaşma yaptı (Floor ve Clawson 2000: 358). ${ }^{2}$ Bu antlaşmaya göre; Hollandalı tüccarlar İran'da serbestçe ticarî faaliyetlerde bulunacak ve Hollanda gemileri İran'a getirdikleri malzemeleri Şah'ın özel depolarına boşaltıp, karşılığında İran ürünü(ipek, halı, yün, kumaş) alacaklardı (Mihriban 1387: 168). Rudi Matthee, Hollandalıların bu antlaşma ile Şah Abbas'a yılda 600 balya mal alacaklarını taahhüt ettiklerini söylemektedir (Matthee 2000: 237). Hollanda, bu antlaşmanın imzalanmasından sonra Şah Abbas' bir teşekkür mektubu yollamıştır. Fakat burada bir husus daima Hollandalı tüccarların şikayetine sebep oluyordu. Hollandalılar, Bender Abbas'da gümrük vergisi ödemekten geri duruyorlardı. Çünkü toplanan gümrük vergilerinin yarısı yukarıda bahsettiğimiz antlaşma gereği İngiltere'ye ait Doğu Hindistan Kumpanyasi'na gidiyordu. ${ }^{3}$ Hollanda bunu menfaatlerine uygun bulmadığından ödeme yapmak istemiyordu. Hollandalı tacirler, İranlı tüccarlarla ortak olup, İngilizlerle rekabet halinde olduklarından gümrük vergisi konusuna sürekli itiraz ediyorlardı. Bu noktada herhalde Şah Abbas, bir süre Ingiltere'ye Bender Abbas'ın gümrük gelirlerinden ödeme yapmış olsa bile daha sonra bunu bazı bahanelerle kesmiş olmalıdır. Çünkü herhalde buna bir tepki olarak İsfahan'daki İngiltere'ye ait ticaret merkezinin başkanı Thomas Kerridge, şehirdeki tüm şubelerini kapatmıştır. Bunun sonucunda ticaret merkezleri Hollandalıların eline geçmiştir. Bununla yetinmeyen Hollanda, Şiraz ve Kirman'da ticaret merkezleri kurup, çalışmalarına devam etmiştir (Pâzuki 13ı̈: 345).

1627 yılında İngilizlere ait Doğu Hindistan Kumpanyası temsilcisi William Burt, İran'a ulaşmış ve Şah Abbas ile bir antlaşma yapmak istemişti. Burt, İran'dan satın alınacak ham ipek karşılı̆ıında ödemenin dörtte birinin nakdi, geri kalanının aynî (İngiliz yünlüleri veya diğer İngiliz ürünleri) olarak yapılması hususunu Şah'a kabul ettirmek için büyük ümitlerle İran'a gelmişti (Ferrier 1986: 57-58). Görüşmelerden sonra Burt'un teklifi kabul edildi (1628) ve ödemenin dörtte birinin nakit, dörtte üçünün de İngiliz ürünleriyle yapılması şeklinde bir antlaşmaya varıldı (Ferrier 1973: 46). Bu isim, Şah Abbas zamanında İran'a gelen kumpanyanın bildiğimiz son temsilcisidir. William Burt, 1630 yılında vefat edince onun yerini Edward Heynes alacaktır.

\footnotetext{
${ }^{2}$ Şah'ın Hollandalılarla bir ticaret antlaşması yapmasındaki gayelerinden biri de nakit paraya olan ihtiyacıydı. Aldıkları ipek veya ticaret malı karşılığında Hollandalılar ödemenin üçte birini nakit olarak [madeni para] yapmayı taahhüt etmişlerdi. Fakat bu taahhütlerini her zaman tam olarak yerine getirmemişlerdir. Örneğin 1628 yılında yaptıkları 17.153 tümenlik ticaret gereği üçte birlik pay olan 5712 tümenlik bir ödeme yapmaları gerekirken bunun ancak 3000'ini Şah'ın temsilcisine [Mülayim Bey] nakit olarak ödemişlerdi.

3 Şah Abbas, Hürmüz'ün fethi sırasında İngiliz yardımı almak için Bender Abbas'ın gümrük gelirleri gibi bazı taahhütlerde bulunmuştu. Fakat daha sonra Şah'ın bu taahhütleri ne derece yerine getirdiği şüphelidir.
} 
Şah Abbas, 16.yüzyıl sonlarında Osmanlıları büyük ölçüde ipek üreten Azerbaycan eyaletlerinden çıardıktan sonra Irak'ı da fethederek Osmanlı İmparatorluğu'nun bu ekonomik can damarını da kesmeyi planlamakta idi. Şah bununla kalmayarak Halep'i de almak; böylece Avrupa ile Hindistan arasındaki ticareti doğrudan kendi kontrolü altına almayı tasarlıyordu. Bu amaçla 1622'de Hürmüz adasını, yine aynı yıl İran-Hindistan kervan ticaretinin merkezi Kandahar şehrini ve 1623 yılında da Bağdat'ı almayı başarmıştır. Hatta Basra'yı da almak için ordu sevk ettiyse de başarılı olamadı. Bağdat'ın düşmesi üzerine yardım ümidini kesen Basra Paşası ise şehrin güvenliği ve ekonomik geleceği için Portekiz ile bir ittifak yapmak zorunda kaldı. Bağdat'ın Şah'ın eline geçmesi sonucunda Portekizliler tarafından Basra'ya getirilen Hint malları Bağdat'a uğramayarak doğrudan çöl üzerinden Halep'e ulaşmıştır. Buna tepki gösteren İranlılar, Şah Abbas'ın vefatından bir yıl sonra 1630 yılında Bender Abbas limanında İngilizlere imtiyazlar vermişlerdir. Bu sayede transit ticaret sebebiyle Bender Abbas, bir ara Asya'nın önemli limanlarından biri haline geldiyse de Portekizli tüccarlar burayı kullanmayarak Basra'dan Suriye limanlarına ulaşmayı tercih etmişlerdi. Çünkü Hürmüz adasının Safevi hâkimiyetine geçmesi ile Fars körfezi ve Hindistan'daki ticarî durumu sarsılan Portekiz, Basra üzerinden yaptığı ticaret için Maskat'ı merkez yapmıştı (Inalcık 2000: 417). Ayrıca yine Basra'da ticarî bir merkez de oluşturmuştu. Görüldüğü üzere Fars Körfezinde Şah Abbas'ın saltanatının sonlarında bir İran-ìspanya (Portekiz) rekabeti yaşanmıştır.

1623 yılında Şah Abbas'ın önemli bir ticaret merkezi Bağdat'ı alması sonucunda yeni bir İran diplomatik heyeti ispanya, Fransa, Hollanda ve İngiltere'yi ziyaret etti. 80 balya ipekle birlikte Londra'ya ulaşan İran heyetinin amacı bir ittifak ve ticaret antlaşması imzalamaktı. Şah, İngiltere Kralına İran limanlarından her yıl 8.000 balya ipek teslim etmek vaadinde bulundu. Ayrıca Bağdat'tan sonra Halep'i de Osmanlılardan alıp, ipeği bu kısa güzergâh üzerinden yollayabileceği ümidini verdi. Kral l. Charles, karşılık olarak 1626 yılında Şah'a bir heyet yolladıysa da İngilizler, İran yönetiminin istediği miktarda altın ve gümüşün tedarikindeki zorluklar, güney Atlantik rotasının uzunluğu, İspanyol ve Portekizlilerin düşmanlığı ve nihayet Levant Kumpanyasının geleceğine ilişkin belirsizlikler gibi faktörler sebebiyle Şah'ın önerileri konusunda kararsız kalmaya devam etmişlerdir (Inalcık 2000: 305).

Osmanlı Devleti ve Safevi Devleti arasında ticaret denilince ipek akla gelmekle birlikte iki devlet arasındaki tek ticaret emtiası ipek değildi. İranlı tüccarlar ipeğin yanında diğer ticaret mallarının da satımını yapıyorlardı. Bu bağlamda Fars Körfezi üzerinden yapılan ticarete değinmek yerinde olacaktır. Hürmüz'den başlayan bu ticaret ağı, Basra'ya oradan da Bağdat ve Halep'e uzanıyordu. 16. yüzyılda Halep ve Basra, Osmanlı egemenliğinde bölgede asayiş 
ve güvenlik sağlanması sonucu ticarî bakımdan özellikle Hindistan'dan yapılan baharat ticareti sebebiyle ile müthiş bir gelişme göstermişti. İngiliz tüccarlar bile Halep-Basra-Hürmüz-Hindistan rotasını takip ediyorlardı. Osmanlıların Suriye çölünü kontrol almaları sonucu gerek İran ipeği gerekse Hint baharatı ve kumaşları açısından Halep önemli bir antrepo konumuna gelmişti. Halep'te Batılı tüccarların (Venedik, Alman v.s.) yanı sıra İran, Anadolu, Mısır ve Hindistan'dan gelen tüccarlar buluşuyor ve şehir canlı bir ticaret trafiğine sahne oluyordu. Hürmüz'den Basra'ya ulaşan ticaret gemileri buradan kervanlarla Halep'e gidiyorlardı. Bu kervanlarda baharat, pamuk, ilaçlar, çivit ve Hint kumaşları oluyordu. Kervanlardaki tacirler Hintli Müslümanlar, Bağdat ve İran tüccarları idiler. Arap tüccarları doğrudan Hürmüz'den mal alıyorlardı. Bu ticarete Batılılar özellikle Venedikli tüccarlar katılıyorlardı. İran tüccarının taşıdığı mallar arasında Lahor kumaşları ve çivit yer alıyordu. Osmanlı ülkesi ve İran pazarları için Portekizliler tarafından yapılan ithalat bakımından Basra kuşkusuz en önemli transit ticaret noktası idi. İran'dan Basra'ya yapılan ithalat maddeleri pamuklular, ipek kumaşlar, halı, yün ipliği, keten, gül suyu, kâseler, buğday, un, koyun, davar, kuru meyve idi. Hürmüz'den Basra ve Bağdat'a ithal olunan malların büyük kısmını Arap ve Türk tüccarı alıyordu. Görüldüğü üzere Hindistan'dan başlayıp Hürmüz'den Basra'ya ve oradan da lrak ve Suriye'deki ticaret merkezlerine uzanan yoğun bir ticaret vardı. Eylül 1606 tarihinde Hürmüz'e giden ticaret yolu üzerinde önemli bir kent olan Şiraz'a ulaşan Portekizli seyyah Nicolau De Orta Rebelo, seyahatnamesinde bu canlı ticareti doğrulayacak ifadeler kullanmış ve konakladığı kervansarayda İranlılar, Araplar, Türkler, Hindistanlılar, Venedikliler, Yunanlılar, Ermeniler, Macarlar, Yahudiler ve Portekizlilerin olduğunu yazmıştır (Özbaran 2007: 87). Birçok İranlı tüccar Hürmüz adasına ticaret için gidiyordu. Şah Abbas devrinde İran'da bulunan Portekizli seyyah Teixeira, Portekizli ve diğer Hıristiyan tüccarlar ile ticaret yapmak için İran'ın tüm bölgelerinden Hürmüz'e kervanların geldiğini ve İranlı tüccarların altın, gümüş, ham-işlenmiş ipek, brokar, halı, at, kökboyası, şap, ravent, gül suyu satıp, güzel elbiseler, mendil, karanfil, tarçın, biber, kakule, zencefil, Hindistan cevizi, şeker, kalay, sandal ağacı, Çin porseleni, misk, kıymetli taşlar, inci ve çivit aldıklarını yazmaktadır (Teixeira 1902: 252). Portekizliler bu önemli adayı 1622 tarihinde Şah Abbas'a kaptırıncaya kadar bu transit ticaretten önemli gümrük geliri elde etmişlerdi. Bu dönemde Basra, İran ticareti açısından yalnız yerel maddeler için değil Hindistan menşeli mallar için de çok önemli bir merkez idi. İranlılar genelde Basra'da buğday depoları ve sebzevat pazarıyla halk için başlıca yerel liman olan Sif iskelesine gelirlerdi. Karadan Luristan ve Şiraz'dan kervanlar; denizden Daurak, Bender ve Ebu-Şihr iskelelerinden gemiler düzenli olarak Sife gelirlerdi. Bu limanlarla denizden ve Huvayz, Dizful, Şuşter ve Vasıt ile Karun Nehri üzerinden Basra ile İran arasında çok canlı bir ticaret vardı. Yine İran tüccarı Hint malları ithalinde Basra yolunu kullanıyordu. Basra'ya ithal olunan mallar özellikle ipek ve pamuklu kumaşları ile gıda maddeleri bakımından İran, 
bölge ticareti için önemliydi. Bazı değerli İran ipekli kumaşları Hindistan'a da ihraç olunuyordu. Görüldüğü üzere Basra hem uluslararası hem de bölgesel ticarette önemli bir merkezdi. Son olarak İranlı tüccarların ulaştığı bir nokta da Trablus [Trablusşam] limanı idi. Miktarı fazla olmamakla birlikte İran'dan ve Suriye'den kervan yoluyla Trablus limanına ulaşan mallar (İran ipeği de var) kantar vergisi alındıktan sonra Avrupa'ya taşınıyordu (Inalcık 2000: 396-416).

\section{Venedik ile Ticarî Münasebetler}

Şah Abbas dönemindeki ticarî faaliyetler bahsinde İran'dan Venedik'e giden tüccarlardan da bahsetmek yerinde olacaktır. Haziran 1600'de Esed [Esad] Bey isminde bir tüccar, 6 ya da 8 kişiyle birlikte Halep üzerinden Venedik'e gitmişti. Bu kişi Şah adına mal alıp satma ve Venedik'te göreceği Sherley'e para sağlama işiyle görevlendirilmişti. Fakat bu şahıs, Şah Abbas'ın elçisinin gelişini Osmanlı Sultan'ı duyar diye telaşlanan Venedik Dük'ü tarafından hemen geri gönderilmiştir (Ross 1933: 33). Esed Bey, İran’a geri dönüş yolculuğunda Bağdat'ta ölmüştür. 16 Mayıs 1602'de Venedikli bir tüccar olan Angelo Gradenigo, Düka tarafından kabul edildi. Bu kişi, Anthony Sherley ve Hüseyin Ali Bayat ile ilgili bilgiler toplamak ve üzerinde altın harflerle Şah'ın adı yazılı olan demir bir eldiveni Venedik dükasına sunmak üzere Şah 1. Abbas tarafindan gönderilmişti. 5 Mart 1603 tarihinde bu defa Şah'ın saray görevlilerinden[saray tedarikçisi] Fethi Bey ve Muhammed Emin, maiyetlerindeki 9 kişiyle Venedik'e geldi. Fethi Bey vasıtasıyla Osmanlılarla arasında gerginlik olan Venediklilere ittifak teklif eden Şah Abbas'ın önerisi, tekrar Osmanlılarla savaşmaktan çekinen Venedik Devleti tarafından sıcak karşılanmadı ve böylece bu girişimden bir netice elde edilemedi (Mehdevi 1377: 74). Şah'ın gönderdiği bu saray tedarikçileri, Şah'ın emri doğrultusunda Venedik'ten savaş malzemesi almışlardı. Fakat Fethi Bey, yeni bir Osmanlı-Safevi Savaşı (1603-16ı2) çıktığını öğrenince, İran'a geri dönüşünde Suriye'den geçmek zorunda olacağından Osmanlı otoriteleri tarafindan mallarına el konulması tehlikesi nedeniyle mallarından bir kısmını Venedik'te emanete bırakmıştır (Mihriban 1387: 172). Bu malları geri alma ümidi, Şah Abbas'ı iki Ermeni tüccarı Kirakos ve Safar'ı [Hoca Sefer, Hâce Safer] Venedik'e göndermeye sevk etti. Bu kişiler sırasıyla 1609 ve 1610 yıllarında Venedik'e vardılar. Nasrullah Felsefi, Fransız seyyah Tavernier'i kaynak göstererek kanaatimizce aynı olayı şu şekilde anlatmaktadır: "Şah Abbas, İsfahan'n muteber tüccarlarından birisini Venedik'e gönderdi. Fakat bu kişi [Fethi Bey olmalı], birtakım bahanelerle Venedik makamlarınca yakalandı ve mallarına el konuldu. Şah Abbas, bu olayın çözümü için isfahan'in iki zeki tüccarını [Hâce Safer ve Kirakos olmalı], iki büyük tüccar [Hâce Altun (Alton) ve Matas] ile birlikte Venedik'e yolladı. Bu kişiler adı geçen tüccara ait malları geri alıp, sattılar ve Iran'a döndüler (Felsefi 1375:1122-1123)." Şah Abbas, yukarıda isimlerini saydığımız tüccarların arasından Hâce Safer'e asıl görevinden başka iki 
görev daha vermişti. Bu görevlerin ilki, Şah'ın özel mektuplarını, İspanya Kralı, Papa V. Paul (1605-1621), Karmelit tarikatı lideri ile Toskana ve Venedik Düklerine iletmek idi. Tabii bu görevi tek başına değil Robert Sherley ile icra edeceklerdi. Ikinci görev ise Şah adına [herhalde saray tedarikçisi sıfatıyla] bazı Frenk eşyaları ve elbiseleri satın almaktı. Sözü edilen mektuplardan Papa ve Issanya Kralı'na hitaben yazılanlar, Robert Sherley aracılı̆̆ı sahiplerine iletilmiştir. Hâce Safer, tahminimize göre daha İran sefaret heyeti İtalya'da iken Robert Sherley'den ayrılmıştır. Floransa'ya giden Hâce Safer, Toskana Dük'üne yazılan mektubu Dük'e iletmiş, ayrıca burada esir olarak bulunan yedi ìsfahanlı ve Kazvinli İran vatandaşını [muhtemelen Ermeni tüccarlar] Şah adına bağışlatmayı başarmıştı. Daha sonra bir müddet Milano'da kalan Hâce Safer'in bu tarihten rapor $^{4}$ gönderdiği 1619 yilına kadar nerelerde ve ne gibi faaliyetlerde bulunduğunu tam olarak tespit edemedik. Fakat bildiğimiz bir şey vardır ki o da sebebi bilinmemekle birlikte Hâce Safer'in İran'a hiçbir zaman geri dönmediğidir. 1613 yılında ise iki İranlı tüccar Alaaddin Muhammed ile Şehsuvar Venedik'te idiler. Şehsuvar, Hacı İvaz Tebrizi, İmad ve diğerleri 1622 yılında İran'a geri dönmüşlerdir. Bunların hepsi saray tedarikçisi olarak takdim edilmişlerdi (Rota 2002: 901).

Şah Abbas'in heyetlerini Venedik'e göndermesine karşıllk Venedik otoritelerinin karşılık verme zahmetine katlanmadıkları görülmektedir. 1608 yılında Şah Abbas, Halep'teki Venedik konsolosu Giovanni Francesco Sagredo'ya "iran konsolosu" unvanını vermiş ve 1611 yılında onu Venedik şehri ile bütün Venedik toprağında kendisinin "genel vekili" olarak atamıştı. Bu şahsın yeğeni Alvise, 1627 yılında İran'a gelmeye ve orada ticaret yapmaya çağrıldı. Venedik senatosu, 1629 yılında gerekli izni verince Alvise İran'a doğru yola çıktı. Fakat Hüsrev Paşa'nın gerçekleștirdiği askeri seferden dolayı yolun kapalı olmasından İran'a ulaşamad. Böylece Alvise Sagredo'nun kara yoluyla gerçekleştirilen ipek ticaretinin Venedik'e kaymasını sağlama ve İran'da bir Venedik ticaret üretimhanesi kurma yönündeki iddialı planı bu şekilde sonuçsuz kalmıştır (Rota 2002: 901). Görüldüğü üzere Şah Abbas zamanında Venedik ile ilişkiler daha çok ticarî ve ekonomik mahiyette olup siyasi bir nitelikten yoksundular. Aslında Venedik ve İran müşterek düşman Osmanlı Devleti'ne karşı hep işbirliği içinde olmaya çalışmış devletler olup, bunun tarihçesi Uzun Hasan'a kadar gitmektedir. Fakat Şah Abbas zamanında bu ilişkilerin siyasi bir boyut kazanamamasına veya fiili bir ittifak yapılamamasına sebep olarak, herhalde iki ülkede savaşa uygun şartların hiçbir zaman aynı anda ortaya çıkmaması ve iki devletin bazen hoşnut

\footnotetext{
${ }^{4}$ Hâce Safer, Şah Abbas'a Roma'dan 21 Ağustos 1619 tarihli bir rapor göndermiştir. Bu raporun tam metnine ulaşamadık ama N. Felsefi, kitabının 3. cildinin Ek'ler kısmında adı geçen raporun bir bölümünü okuyucuya sunmaktadır. Biz bu bölümden yararlandık.
} 
olmasalar da Osmanlı Devleti ile ticarî faaliyetlerini sürdürüyor olmaları gösterilebilir.

\section{Özbek ve Babürlülerle Olan Ticarî Münasebetler}

16. yüzyılın sonları ve 17. yüzyılda, İran-Türkistan-Hindistan arasında yoğun bir ticarî faaliyet yaşanıyordu. Safevi hükümdarı Şah Abbas, Özbek Han'ı 11. Abdullah Han ve Babür hükümdarı Ekber Şah, hâkimiyetleri altındaki topraklarda yolları tamir ettiriyorlar, ticaret güzergâhlarının güvenliğini sağlıyorlar ve tüccarlar için kervansaraylar yaptırarak ticaretin gelişmesine ve ülkelerinin refahına hizmet ediyorlardı. Safeviler, Hindistan'dan genelde tekstil, şeker ve çivit alırlarken, Babürlüler İran'dan ipek, lüks eşya, kıymetli metal, kavun, kurutulmuş kayısı ve badem alıyorlardı. Tabii İran'ın Hindistan'a sattığı en önemli ticarî meta atlardı. Çünkü Hindistan'daki Babür askeri düzeninin atlara ihtiyacı vardı. Fakat bu at ticareti izne bağlıydı. ilişkiler gergin olduğunda Babür hükümdarları güherçile satışını yasaklarken Safevi hükümdarları da at satışını engelliyorlardı. Örneğin devletten izinsiz olarak Hindistan'a at götüren bir Ermeni tüccar, Hürmüz'e giderken yolda yakalanmış ve ceza olarak bir oğlu Şah Abbas'in gulamları arasına dâhil edilmişti (Felsefî 1375: 962).

İran-Hindistan arasındaki ticaretin odak noktasını Kandahar oluşturuyordu. Bu ticarî önem itibariyle Kandahar hâkimlerinin bir görevi de ticaret yollarının güvenliğini sağlamak idi. Kandahar üzerinden yürütülen kervan ticaretinde milyonlarca tümenlik akış vardı ve her yıl yaklaşık olarak 25.000 deve, Hindistan dokumalarıyla i̇sfahan'a ulaşıyordu. İran-Hindistan arasında deniz yoluyla yapılan ticarette ise iki önemli liman vardı. Bunlar Bender Abbas ve Surat limanları idi (Islam 1970: 172). Babürlüler, Fars Körfezi'nden gümüş alıyorlardı. Örneğin 1588-1602 yılları arasındaki dönemde İran, Hindistan'a 27,8 ton gümüş ihraç etmişti (Floor ve Clawson 2000: 348). Tabii nakit paraya ihtiyaç hâsıl olduğu savaş durumlarında Şah Abbas ülkesinden kıymetli maden[madeni para] çıkışııı yasaklıyordu. Hatta Şah'ın $16 ı 8$ yılındaki fermanını dinlemeyip, ülke dışına kaçak gümüş veya altın çıkaran bazı tüccarlar öldürülmüştü.

Şah Abbas döneminde Özbek Hanlı̆̆ı ile yapılan ticarete gelince, Buharalı tüccarların faaliyetlerine değinmek gereklidir. Özbek tüccarlar İran'a tavuk, ıspanak, erik, kavun, atlar da dâhil olmak üzere çiftlik hayvanları, lacivert taşı, sinameki, ravent kökü, misk, ham ipek, tütün, kenevir, parfüm (kokular), kâğıt, kuzu derisinden yapılma mantolar (kürkler), halı, eyer takımları, Sibirya samur ve siyah tilkileri (herhalde kürkleri) satarlarken karşlığında yünlü ve keten kumaşlar ile çeşitli ipekliler alıyorlardı. Herat'ın sarıkları (türbanları), Kaşan ve Yezd'in ipeklileri Özbek Hanlığı'na satılıyordu. İsfahan'daki Muhammed 
Bek Kervansarayı'na Semerkant, Kirman ve Meşhedli tüccarlar geliyorlardı (Burton 1997: 440-443).

\section{Şah Abbas Devrinde iç Ticaret}

Şah Abbas zamanında uluslararası ticaretin yanında İran'ın dâhili ticareti de gelişme göstermiştir. Bu, Şah'ın ülkesinde yeni yollar ve köprüler inşa ettirmesi ve mevcut kara yollarını iyileştirmesi ile bu yollar üzerinde haydutluk yapanları sıkı takibe tutup cezalandırmasının bir sonucudur. Şah Abbas'ın yoğun yağışlardan dolayı yolları çamurlu olan Gilan ve Mâzenderan'ı birbirine bağlayan meşhur Seng Ferş adl $\mathbf{1} 45$ fersah [ $280 \mathrm{~km}]$ uzunluğundaki taş döşeme yolu yaptırması Hazar kıyısı eyaletlerini doğudan batıya bağlamıştı (Sykes 19ı5: 265). ülkesinde ulaşıma önem veren Şah Abbas ayrıca Câcrem'den Mukan [Mugan] Ovası́na kadar olan yolları da onartmıştı. Şah Abbas, yolların bakımını ve güvenliğini şehir hâkimlerine bırakmış ve bu hakimlerin gelir sağlamaları için kendi bölgelerinden geçen ticaret kervanlarından vergi almalarına izin vermişti. Böylece hâkimler merkezden gönderilecek bir paraya ihtiyaç duymadıkları gibi topladıkları paranın bir kısmını da Şah'a [merkezi hazineye] yolluyorlardı. "Rahdâri" adı verilen görevliler, yerel yöneticilerin kontrolü altında yolların güvenliğinden sorumluydular. Yol vergisi koyan Şah Abbas, her bir yük deve için 13 Abbasî (2,5 riyal) vergi aldırıyor ve bunu yolların bakımı ve güvenliği için harcattırıyordu (Fâikî 1375: 823). Bu sayede yollarda güvenlik ve rahat ulaşım sağlanınca iç ticaret de gelişme göstermişti. Şah'ın ülkedeki huzuru ve güveni sağladıktan sonra etkili bir yönetim ağı oluşturmaya çalışması, büyük bir enerjiyle ticaret rotaları oluşturması, belirli fasılalarla bu rotalar üzerinde kervansaraylar yaptırması ve sınırlarda posta teşkilatı kurdurması da iç ticaretin gelişmesine yardımcı oluyordu. Kervansarayları çalıştıran görevliler, tüccarların güvenliği ve çalınan eşyalardan sorumlu tutuluyorlardı. Portekizli seyyah Rebelo, Şiraz'da kaldığı kervansarayın çok güvenli olduğunu, çalınan herhangi bir nesnenin karşılı̆ıının nöbetçilere ödettirildiğini ve bunlara ayrıca ağır cezaların verildiğini yazmaktadır (Özbaran 2007: 88). Yine İtalyan seyyah Della Valle, İran'da seyahat etmenin güvenli olduğunu yazmaktadır (Pinkerton 1811: 20). Şah Abbas'in emri gereğince eğer bir seyyah, tüccar veya ahaliden biri soyulursa bulunduğu yörenin yöneticisi bu işi çözmeye veya kendi hazinesinden tazmin etmeye mecburdu. Safevi ülkesinin uluslararası dış ticareti Ermenilerin elindeyken, iç ticareti Yahudi ve İranlıların elinde idi.

\section{Sonuç}

Şah Abbas devrinde en fazla ticaret Türkiye ve Hindistan ile yapılyyordu. Türkiye'den ithal edilen maddelerin başında bakır geliyordu. Ayrıca gümüş ve altın da ithal olunuyordu. Çünkü İran, kendi üretmediği bu kıymetli madenlere hem silah yapımı hem de madeni para basımında ihtiyaç duyuyordu. Bu 
sebepten Şah Abbas ve diğer Safevi şahları dış ticareti açık tutmak zorundaydılar. Bunun karşılı̆ında ise Osmanlı Devleti, ipek endüstrisi için İran'ın ham ipeğine muhtaçtı. Ayrıca Avrupa'ya olan transit ticaretten muazzam gelir elde ediyordu. Kısacası iki devlet de karşılıklı ticarete fazlasıyla muhtaçtılar. İran'ın başlıca ihraç malı olan ipek, kervanlar ile bilhassa Tokat ve Halep'e gönderiliyordu (Sümer 1990: 22). Tabii çok büyük bir ipek pazarı olan Bursa'yı da unutmamak gereklidir. Türkiye'ye gelen ipeğin mühim bir kısmı Avrupa'ya sevk olunuyor ve Türkiye bundan mühim bir kazanç sağlıyordu. Şah Abbas, bu geliri kesmeyi düşünmüşse de teşebbüsleri sonuçsuz kalmıştı. 16. yüzyıl ile 17. yüzyılın ilk yarısında Venedik, Osmanlı Devleti ve İran, dünya ticaretinin ana arteri olan Hindistan-Yakındoğu ticaretinden önemli gelir elde etmişlerdi. Hatta İran, Şah Abbas döneminde en yüksek ticaret hacmine ulaşmıştı. Bu ticarette başta ipek ve Hint baharatı olmak üzere pek çok yerel ve uluslararası mallar taşınmakta ve adı geçen üç ülkenin önemli ticaret merkezleri canlı bir ticarî hayata sahne olmaktaydı. İran hem ürettiği ipeği ve bazı yerel ürünlerini satıyor hem de Hint mallarının Osmanlı toprakları aracılığı ile Batı́ya taşınmasında aracılık yaparak önemli bir ticarî gelir elde ediyordu. İran, sadece Osmanlı Devleti ile Hindistan arasındaki bağlantıyı sağlamakla kalmıyor, aynı zamanda Arab yarımadası ile Rusya arasındaki bağlantıyı da sağlıyordu (Matthee 2000: 224). İran'ın dış ticaretinde özellikle de İran ipeğinin taşınmasında, Culfa Ermenileri öne çıkmaktaydı. Fars körfezindeki deniz ticaretinde ise özellikle Portekizli tüccarlar faal rol oynuyor, İranlı tüccarlar ise -1622 yılına kadarPortekiz hâkimiyetinde olan ve körfezin anahtarı olan Hürmüz adasını kullanıorlardı. Tabii bunun karşılı̆̆ında Portekizlilere gümrük vergisi ödüyorlardı. Fakat 17. yüzyılın ilk yarısının sonlarına doğru Fars Körfezinde ispanya ve Portekiz' in yerini, deniz ticaretinde ağırlıklarını hissettiren İngiltere ve Hollanda almaya başlayınca, İran tüccarı Hint mallarını bu iki devlete ait Doğu Hindistan Kumpanyaları aracılığı ile almaya başlayacaktır. Tabii burada şu hususu da belirtmekte fayda vardır ki Hindistan-Yakın Doğu ticareti (Hindistanİran-Osmanl-Avrupa) 17. yüzyılın ortalarından itibaren Atlantik ekonomisinin muazzam gelişmesi sonucu eski önemini yitirecek, bu ticaretin yerini Amerika kolonilerinde yetiştirilen şeker, tütün, kahve ve pamuk ticareti alacaktır. Buna ek olarak pamukluların moda olmasıyla ipek ticaretinin önemi azalacak, İngiliz ve Hollanda Doğu Hindistan Kumpanyalarının Basra ile Kemburun Limanına yaptıkları ithalatta ipeğin yerini pamuk almaya başlayacaktır. Böylece 17. yüzyılda koloni ürünlerinin dünyada hızla yayılışı karşısında Ortadoğu ticareti önemini kaybedecektir. Hindistan-Yakın Doğu ticareti dünya ticaretindeki en önemli ana yol olma özelliğini kaybedince bundan Venedik, Osmanlı Devleti ve İran etkilenecektir. Bu üç devlet, dünya ticaretinde oynadıkları aracı rolü korumak için tüm 16. yüzyıl boyunca uğraşsalar da değişim kaçınılmaz olacaktır. Bu değişim, İran'da Şah Abbas'ın saltanatının son dönemlerinde hatırı sayılır bir 
şekilde kendini hissettirmeye başlayacak ve sonraki Şahlar döneminde de hızla devam edecektir.

Şah Abbas, ömrü boyunca iç ve dış ticareti geliştirmeye, bu suretle İran'ın itibarını ve ekonomisini yükseltmeye çalışmış ve bunda muvaffak olmuştu. Akıllı bir hükümdar olan Şah Abbas, İran ticaretinin zarar görmemesi için yabancı tüccar ve temsilcilerin ipeğin fiyatının sabitlenmesi hakkındaki önerilerini kesinlikle kabul etmemişti. Böylece İran'a gelen yabancı mallar pahalı olduğunda ipeğin fiyatı da yükseltilerek denge sağlanabiliyordu. Şah Abbas'ın devlet otoritesini yeniden tesis edip, iç ve dış ticareti geliştirerek İran'ın ekonomik durumu düzeltmesi ve canlandırması Avrupa ülkeleriyle olan diplomatik ilişkileri de yoğunlaştırmıştı. Onun başarılı faaliyetleri sonucunda Batılı diplomatik temsilciler İran'a yönelmişlerdi. Böylece kurulan çok yönlü ilişkiler sonucunda hem ekonomik hem de ticarî faaliyetler hız kazanmış ve Safevi Devleti'nin refah düzeyi yükselmiştir. Bunu çağdaş Osmanlı kronikleri de eserlerinde belirtmișlerdir. Örneğin Naima Mustafa Efendi, Şah Abbas dönemi İran'ı için "memleketi ma'mûr [bayındır] ve malı bî-had ü mevfûr [sınırsız bir şekilde çok] idi" demektedir (Naîmâ 2007:644).

\section{KAYNAKÇA}

BURTON, Audrey, The Bukharans: A Dynastic, Diplomatic And Commercial History (1550-1702), Great Britain: Curzon Press, 1997

ÇAY, Abdulhâluk, "Safaviler-Avşarlar-Kaçarlar", Tarihte Türk Devletleri, Ankara: Ankara Üniversitesi Rektörlüğü Yayınları, ll (1987): 565-566

FÂikî, ibrahim, Azerbaycan Mesîr-i Tarih-i İran, Tebriz: İntişarât-1 Yâran, 1375, C. 11.

FARMAYAN, H. F., The Beginnings of Modernization in Iran: The Policies and Reforms of Shah Abbas 1 (1587-1629), Salt Lake City, Utah: Middle East Center University Of Utah, 1969

FELSEFi, Nasrullah, Zendegâni-yi Şah Abbas-1 Evvel, İntişârât-1 ilmî, Tahran, 1375, C. 1-V

FERRIER, R. W., "The Armenians and the East India Company in Persia in the Seventeenth and Early Eighteenth Centuries", The Economic History Review, New Series, 26 (1/1973): 38-62

FERRIER, R. W., "The Terms And Conditions Under Which English Trade Was Transacted With Safavid Persia", Bulletin Of The School Of Oriental And African Studies, University Of London, (In Honour Of Ann K. S. Lambton), 49 (1/1986):48-66

FLOOR, W., - CLAWSON, P., "Safavid's Iran Search For Silver And Gold", International Journal of Middle East Studies, 32 (3/2000):345-368

ISLAM, Riazul, Indo-Persian Relations, Iranian Culture Foundation, Teheran, 1970.

iNALCIK, Halil, Osmanlı İmparatorluğu'nun Ekonomik ve Sosyal Tarihi, Çev: Halil Berktay, istanbul: Eren Yayıncilık, 2000, C. I

iSKENDER BEY TÜRKMEN, Târih-i Âlem-ârâ-yi Abbasi, Yayına Hazırlayan: İrec Af̧sar, Tahran: Müessese-i İntişârât-1 Emir Kebîr, 1387, C. 2

MATTHEE, Rudi, "Between Venice And Surat: The Trade In Gold In Late Safavid Iran", Modern Asian Studies, 34 (1/2000): 223-255

MATTHEE, Rudolph, The Politics Of Trade in Safavid Iran: Silk for Silver 1600-1730, Cambridge University Press, 1999 
Şah Abbas (1587-1629) Devrinde İran'da Ticarî Hayat

${ }^{\text {TAED }} 48^{*} 385$

MEHDEVî, A. H., Târih-i Revâbıt-ı Hârici-i İran: Ez ibtidâ-i Devrân-i Safeviyye Tâ Pâyan-ı Ceng-i Dovvom-1 Cihânî (1500-1945), Tahran: Müessese-i İntişârât-1 Emir Kebir, 1377

MiHRiBAN, M.N.E., Şah Abbas-1 Kebîr: Zendegi ve Neberdhâ-yi Kahraman-1 Bozorg-1 Milli, Tahran: Şirket-i Mütalaât ve Neşr-i Kitâb-1 Parsa, 1387

NAîMÂ MUSTAFA EFENDi, Târih-i Na'îmâ, Haz. Mehmet İpşirli, Ankara: Türk Tarih Kurumu, 2007

ÖZBARAN, Salih, Portekizli Seyyahlar: İran, Türkiye, Irak, Suriye ve Mısır Yollarında, İstanbul: Kitap Yayınevi, 2007

PÂZÛKi, Rıza, Târih-i İran: Ez Moğol Tâ Afşâriyye, Şirket-i Çaphâne-i Ferheng, 1317

PINKERTON, John, A General Collection Of The Best And Most Interesting Voyages And Travels, London, 1811, C. 9

RAMAZANi, R. K., The Foreign Policy Of Iran: A Developing Nation In World Affairs (1500-1941), Charlottesville, United States Of America: University Press Of Virginia, 1966

ROSS, E. Denison, Sir Anthony Sherley and His Persian Adventure, London: George Routledge \& Sons, Ltd, 1933

ROTA, Giorgio, "Safevi İranı ile Venedik Cumhuriyeti Arasındaki Diplomatik ilişkilere Genel Bir Bakış", Türkler, Yeni Türkiye Yayınları, Ankara, 6 (2002): 899-906

SAVORY, R. M., İran Asr-ı Safevi (Iran Under The Safavids), (Ingilizce'den Farsça'ya Çev: Kambiz Azizi), Tahran: Neşr-i Merkez, 1374

SAVORY, R. M., “The Sherley Myth", Studies On The History of Safawid Iran, Variorum Reprints, London, (1987): 73-81

SÜMER, Faruk, “Abbas 1", DiA, İstanbul, 1 (1988): 17-19

SüMER, Faruk, "Safevi Tarihi ile ilgili Incelemeler: l. ve Il. Abbas Devirleri", Türk Dünyası Araştırmaları, 69 (1990): 9-32

SYKES, Percy, M., A History of Persia, London: Macmillan \& Co. Ltd, 11 (1915)

TÂCBAHŞ, Ahmed, İran Der Zaman-1 Safeviyye, Tebriz, 1340

TEIXEIRA, Pedro, The Travels Of Pedro Teixeira With His Kings of Harmuz and Extracts From His Kings Of Persia, (Ingilizce'ye Çeviren ve Dipnot Ekleyen: William F. Sinclair ve Donald Ferguson), London: Hakluyt Society, 1902 